\title{
THE MECHANISM OF HEMOLYSIS IN PAROXYSMAL COLD HEMOGLOBINURIA. I. THE ROLE OF COMPLEMENT AND ITS COMPONENTS IN THE DONATH- LANDSTEINER REACTION 1, 2
}

\author{
By WILLIAM S. JORDAN, JR., LOUIS PILLEMER, AND JOHN H. DINGLE
}

\author{
(From the Departments of Preventive Medicine and of Medicine, and the Institute of Pathology, \\ School of Medicine, Western Reserve University, and the University Hospitals, \\ Cleveland, Ohio)
}

(Submitted for publication July 24, 1950; accepted, October 3, 1950)

Donath and Landsteiner demonstrated that the abnormal factor responsible for hemolysis in paroxysmal cold hemoglobinuria $(\mathrm{PCH})$ is in the patient's serum (1). Inactivation of the serum by heat prevented hemolysis, but the addition of fresh serum restored the activity. The hemolytic reaction in vitro was shown to occur in two phases: 1) a cold phase during which antibody (hemoly$\sin$ ) is adsorbed on the erythrocytes; 2) a warm phase during which the sensitized cells are lysed in the presence of complement (fresh serum). ${ }^{3}$

Subsequent investigators $(2 a-4)$ found that the addition of fresh complement, as contained in a 1-5 or a 1-10 dilution of guinea pig serum, sometimes failed to restore the hemolytic activity of $\mathrm{PCH}$ sera inactivated at temperatures ranging from $45^{\circ} \mathrm{C}$ to $56^{\circ} \mathrm{C}$. It was concluded, therefore, that the hemolysins from various patients differed in heat-stability. Furthermore, the question was raised as to the need for complement during the cold phase of the reaction (2a-9). Some (4-8) indicated that union of hemolysin and erythrocytes took place in the cold only in the presence of complement. Others $(2 a, 3,9)$ observed hemolysis when complement was added only after the mixture of inactivated serum and erythrocytes had been chilled and warmed. On the basis of his studies (2a) and after reviewing the findings of others, Mackenzie (3) concluded 1) that complement was essential for the completion of the hemolytic process, 2) that it need not be present dur-

\footnotetext{
1 Presented at the Forty-second Annual Meeting of the American Society for Clinical Investigation, Atlantic City, May 1, 1950.

2 This investigation was supported in part by grants from the Brush Foundation, the Cleveland Foundation, the S. P. Fenn Trust, and Mr. Philip R. Mather.

8. Complement and fresh serum are used interchangeably throughout this paper.
}

ing the cold phase but caused greater hemolysis if present throughout the reaction, and 3) that, when present, the "midpiece" of complement was adsorbed in the cold by the erythrocyte-lysin complex. Recently Siebens, Zinkham, and Wagley (10) reported that complement is required in both the cold and warm phases of the DonathLandsteiner reaction. Evidence of erythrocyteantibody inter-action was obtained not only by hemolysis but also by agglutination by antiglobulin serum.

Studies of sera from two patients have provided further data on the nature and behavior of hemolysin and on the role of complement in paroxysmal cold hemoglobinuria. These data show that this hemolytic system is unique in two respects: $a$ ) complement is required for antibody fixation as well as for subsequent hemolysis, and $b$ ) only two of the four components of complement are necessary.

\section{MATERIALS AND METHODS}

\section{Hemolysin titration}

Reagents were added for the Donath-Landsteiner reaction to give a final volume of $1 \mathrm{ml}$. as follows: $0.25 \mathrm{ml}$. of serum, $0.25 \mathrm{ml}$. of guinea pig complement and $0.5 \mathrm{ml}$. of 5 per cent suspension of erythrocytes. This method utilized equal volumes of serum and complement and a larger volume of cells than recommended by Mackenzie (2a). It was found to be more sensitive because the intensity of color in the supernatant was easier to estimate than the volume of remaining erythrocytes. In titration, serial two-fold dilutions of the patient's serum in buffered, physiologic saline solution (2b), pH 7.4, and freshly reconstituted "lyovac" guinea pig serum, diluted 1-2, were added to each tube. After addition of erythrocytes (of same group, or group 0 ), the mixture was chilled for 30 minutes in an ice bath, warmed for 30 minutes in a $37^{\circ} \mathrm{C}$ water bath, centrifuged, and the supernatant read for hemolysis. Certain modifications of this procedure, such as varying the complement dilutions 
and washing the erythrocytes between the cold and warm phases, are indicated in the individual protocols. Cells so washed were incubated in $0.25 \mathrm{ml}$. of the appropriate complement dilution.

\section{Agglutination by anti-human serum rabbit serum (antiglobulin serum)}

Immune rabbit serum (11) was produced by the daily intravenous injection of $0.1 \mathrm{ml}$. of group $\mathrm{O}$ human serum. Three seven-day courses of injections were given with an interval of one week between each course. The serum was heated at $56^{\circ} \mathrm{C}$ for 30 minutes, and erythrocyte agglutinins were adsorbed by incubation with pooled group A, $B$ and $O$ red blood cells. After three adsorptions, a 1-2 dilution of the serum did not agglutinate normal cells. When tested against $\mathrm{Rh}$ cells sensitized with hyperimmune $\mathrm{Rh}$ antibodies, the agglutinating titer of the serum was 128 to 256 . The serum produced a visible precipitin reaction with a 1-15,000 dilution of human serum. An initial dilution of $1-4$ anti-human serum rabbit serum was used in the following tests:

\section{Coombs tests}

Antiglobulin serum was used to detect the presence of antibody on the surface of erythrocytes. Erythrocytes sensitized in vivo were agglutinated in the Direct Coombs test; erythrocytes sensitized in vitro, by chilling in $\mathrm{PCH}$ serum, were agglutinated in the Indirect Coombs tests.

\section{Direct}

The patient's erythrocytes were washed three times with saline solution, made up to a 2 per cent suspension, and added in a volume of $0.2 \mathrm{ml}$. to an equal volume of serial two-fold dilutions of antiglobulin serum. After incubation for one hour at $37^{\circ} \mathrm{C}$, the tubes were examined for agglutination by agitation over a magnifying mirror. The titer is expressed as the reciprocal of the highest dilution of antiglobulin serum producing agglutination.

\section{Indirect}

Two different procedures were used to detect the adsorption of antibody by erythrocytes chilled in $\mathrm{PCH}$ serum. In the first, (a), cells were chilled in whole serum, and then tested as in the direct Coombs test. In the second, (b), cells were chilled in different dilutions of $\mathrm{PCH}$ serum and tested with a constant amount of antiglobulin serum.

Indirect (a) : $\mathrm{PCH}$ serum, guinea pig complement and cells were added in the same proportion, but in twice the volumes used for hemolysin titration: $0.5 \mathrm{ml}$. serum; $0.5 \mathrm{ml}$. of a 1-2 dilution of complement; and $1.0 \mathrm{ml}$. of a 5 per cent erythrocyte suspension. The mixture was chilled in the ice bath for 30 minutes and centrifuged. The cells were washed three times with cold saline solution, made up to a 2 per cent suspension, and tested for agglutination after incubation at $37^{\circ} \mathrm{C}$ for one hour in dilutions of antiglobulin serum. In this test, the patient's serum was not diluted and the antiglobulin serum was diluted. As in the direct Coombs test, the titer is the reciprocal of the highest dilution of antiglobulin serum producing agglutination. This titer reflects only indirectly the amount of antibody adsorbed by the cells (12).

Indirect $(b)$ : To determine the agglutinating capacity of the patient's serum, serial two-fold dilutions of the serum were made in $0.2 \mathrm{ml}$. of saline. Two-tenths $\mathrm{ml}$. of a 2 per cent suspension of erythrocytes and $0.2 \mathrm{ml}$. of a 1-2 dilution of complement were then added. After chilling for $\mathbf{3 0}$ minutes in ice water, the cells were washed three times with cold saline solution and resuspended in $0.2 \mathrm{ml}$. of saline. Then $0.2 \mathrm{ml}$. of a 1-4 dilution of antiglobulin serum was added to each tube. After incubation at $37^{\circ} \mathrm{C}$ for one hour, the test was read for agglutination. In this test, the patient's serum was diluted and the antiglobulin serum was not. The titer, comparable to the hemolysin titer, reflects the amount of antibody in the patient's serum.

\section{Complement titration}

The lyovac guinea pig serum and human sera were tested for complement activity in a final volume of $1 \mathrm{ml}$. using $0.4 \mathrm{ml}$. of 1 per cent sheep cells sensitized with four units of amboceptor. That amount of serum producing complete hemolysis after incubation at $37^{\circ} \mathrm{C}$ for 30 minutes was considered to contain one hemolytic unit of complement. The amount of guinea pig complement used in the various tests is expressed as dilutions of freshly reconstituted guinea pig serum. The two lots of serum used were titered periodically, and contained one hemolytic unit of complement in $0.2 \mathrm{ml}$. of a 1-30 dilution, or about 150 units per $\mathrm{ml}$.

\section{Preparation of fractions of guinea pig serum}

The four components of complement have been designated (13) by the following symbols: $C^{\prime} 1, C^{\prime} 2, C^{\prime} 3$, and $C^{\prime} 4$.

Four fractions of fresh guinea pig serum, each lacking one component of complement, were prepared by methods previously described $(14,15)$. In brief, complement lacking either $C^{\prime} 1$ or $C^{\prime} 2$ was prepared by dialyzing serum against acetate buffer of $\mathrm{pH} 5.2$ and ionic strength of 0.02 at $1^{\circ} \mathrm{C}$. The supernatant was neutralized to $\mathrm{pH} 7.2$ with $\mathrm{NaOH}$ and sufficient $\mathrm{NaCl}$ was added to make a final ionic strength of 0.15 ; this fraction lacked $\mathrm{C}^{\prime} 1$. The precipitate was redissolved in phosphate buffer of $\mathrm{pH} 7.2$ and ionic strength of 0.15 ; this fraction lacked $C^{\prime} 2$. Fractions lacking $C^{\prime} 3$ and $C^{\prime} 4$ were prepared by treating serum with zymosan (16) and ammonia, respectively.

Each of the above fractions was inactive when tested at a five unit level. Full complement activity was restored at $a$ one unit level upon the appropriate combination of the fractions.

\section{RESULTS}

Differences in behavior of the sera from two patients with characteristic clinical pictures (see appendix for case summaries) focused attention on the exact role of complement in the Donath-Land- 
TABLE I

A mount of complement needed for antibody fixation and hemolysis

Constant amount of antibody

\begin{tabular}{c|c|c|c|c|c|c|c}
\hline \multirow{2}{*}{$\begin{array}{c}\text { Case } \\
\text { No. }\end{array}$} & \multicolumn{5}{|c}{ Test } & \multicolumn{5}{|c}{ Dilution of complement } \\
\cline { 2 - 7 } & & 2 & 4 & 8 & 16 & 32 & 64 \\
\hline 1 & $\begin{array}{c}\text { Indirect } \\
\text { Coombs (a) } \\
\text { Hemolysin }\end{array}$ & ++++ & ++++ & ++ & + & 0 & 0 \\
\hline 2 & $\begin{array}{c}\text { Indirect } \\
\text { Coombs (a) } \\
\text { Hemolysin }\end{array}$ & +++++ & ++++ & ++++ & ++ & +++ & 0 \\
\hline
\end{tabular}

Indirect Coombs (a) and hemolysin titration-see text under Materials and Methods.

$0=$ No reaction.

+ to $t+++=$ Increasing degrees of reaction; in agglutination test, ++++ indicates disc formation.

steiner reaction. The findings are presented essentially in the order in which the study evolved. It was found that: 1) the Donath-Landsteiner reaction requires a large amount of complement; 2 ) complement must be present during both the cold and warm phases of the reaction; 3) a reciprocal relationship exists between the complement requirements in the two phases and between the amount of complement and the degree of antibody fixation; and 4) the hemolytic reaction requires only two components of complement.

\section{The need for large amounts of complement}

Serum from the first patient was initially active without the addition of guinea pig complement.
After heating at $56^{\circ} \mathrm{C}$ for 30 minutes, the hemolytic activity of the serum was not restored by the addition of a 1-10 dilution of guinea pig serum. Following prolonged storage at $-20^{\circ} \mathrm{C}$, the patient's serum showed barely detectable complement activity. After the addition of a 1-10 dilution of guinea pig serum to restore complement, only slight hemolytic activity was demonstrable. It was assumed, therefore, that the hemolysin had been destroyed by heat and denatured by storage in the frozen state.

With the second patient's serum, however, a positive Donath-Landsteiner reaction could not be demonstrated even after the addition of a 1-5 dilution of guinea pig serum equivalent to eight hemolytic units of complement. The patient's serum was not anticomplementary ; instead it contained one unit of complement in $0.15 \mathrm{ml}$. of a 1-10 dilution. Finally, the addition of a 1-2 dilution of guinea pig serum, equivalent to 20 units of hemolytic complement, did result in hemolysis. It was then noted that serum from the first patient could be restored to its original hemolytic activity by the addition of a 1-2 dilution of complement. In the presence of this amount of complement, the hemolysins from both patients showed maximal activity even after heating at $62^{\circ} \mathrm{C}$ for 30 minutes.

Such stability of the antibody permitted heatinactivation of complement in the patients' sera, and thus the amount of guinea pig complement required for sensitization and hemolysis could be

TABLE II

Antibody levels in two patients with paroxysmal cold hemoglobinuria Constant amount of complement

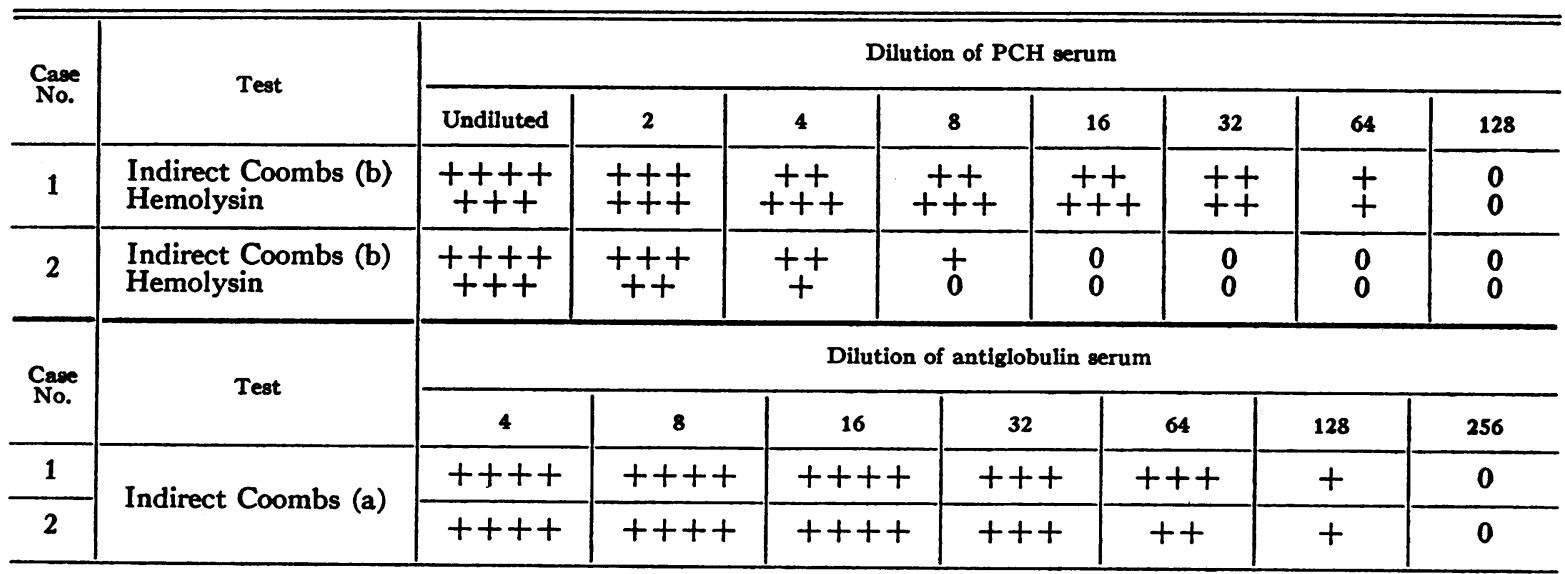

Indirect Coombs test (b) - see text under Materials and Methods.

See footnotes, Table I. 
determined. It is apparent (Table I) that a large amount of guinea pig complement was required. Two to four times as much complement was necessary for hemolysis as was needed for antibody fixation.

There was no significant difference in the amounts of complement required to activate the two sera (Table I), although serum from case 1 had a much higher antibody titer (Table II). Thus, the amount of complement, rather than the hemolysin titer, was the limiting factor in the hemolytic reaction. Adsorption of the sera showed that agglutination of the sensitized cells by dilutions of antiglobulin serum (indirect Coombs [a]) did not distinguish between antibody levels (Table II). The erythrocytes were sufficiently sensitized in the whole sera so that the titers merely reflected the potency of the antiglobulin serum. Adsorption of antibody from dilutions of $\mathrm{PCH}$ serum and the use of a constant amount of antiglobulin serum for agglutination (indirect Coombs [b]), however, did reflect the hemolysin titer (Table II).

The need for complement during the two phases of the Donath-Landsteiner reaction

Studies on sera from both patients confirmed the need for complement during both the cold and warm phases of the reaction. A sample protocol

TABLE III

The need for complement during the two phases of the Donath-Landsteiner reaction

\begin{tabular}{|c|c|c|c|c|c|}
\hline \multirow{2}{*}{ Phase } & \multirow{2}{*}{ Materials } & \multicolumn{4}{|c|}{ Tube No. } \\
\hline & & 1 & 2 & 3 & 4 \\
\hline$\frac{7}{3}$ & $\begin{array}{l}\text { Erythrocytes, } \\
5 \% \text { suspension } \\
\text { Inactivated } \\
\text { PCH serum } \\
\text { Complement, } \\
1-2 \text { guinea pig } \\
\text { serum } \\
\text { Saline solution }\end{array}$ & $\begin{array}{l}0.5 \\
0.25 \\
0.25 \\
0.0\end{array}$ & $\begin{array}{l}0.5 \\
0.25 \\
0.25 \\
0.0\end{array}$ & $\begin{array}{l}0.5 \\
0.25 \\
0.0 \\
0.25\end{array}$ & $\begin{array}{l}0.5 \\
0.25 \\
\\
0.0 \\
0.25\end{array}$ \\
\hline \multicolumn{2}{|c|}{$\begin{array}{l}\text { Agglutination in } \\
\text { antiglobulin serum }\end{array}$} & ++++ & $+t+t$ & $\mathbf{0}$ & $\mathbf{0}$ \\
\hline हू & $\begin{array}{l}\text { Washed Rbc, } \\
5 \% \text { suspension } \\
\text { Complement, } \\
1-2 \text { guinea pig } \\
\text { serum } \\
\text { Saline solution }\end{array}$ & $\begin{array}{l}0.5 \\
\\
0.25 \\
0.0\end{array}$ & $\begin{array}{l}0.5 \\
0.0 \\
0.25\end{array}$ & $\begin{array}{l}0.5 \\
0.25 \\
0.0\end{array}$ & $\begin{array}{l}0.5 \\
0.0 \\
0.25\end{array}$ \\
\hline \multicolumn{2}{|c|}{ Hemolysis } & $+t+$ & 0 & 0 & $\mathbf{0}$ \\
\hline
\end{tabular}

See footnotes, Table I.
TABLE IV

Relationship between complement requirements in two phases of the Donath-Landsteiner reaction

Constant amount of antibody; read for hemolysis

\begin{tabular}{|c|c|c|c|c|c|c|c|c|c|}
\hline & & \multicolumn{8}{|c|}{ Warm phase } \\
\hline & $\begin{array}{c}\text { Dilution } \\
\text { of } \\
\text { complement }\end{array}$ & 2 & 4 & 8 & 16 & 32 & 64 & 128 & 256 \\
\hline 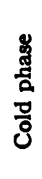 & $\begin{array}{r}2 \\
4 \\
8 \\
16 \\
32 \\
64 \\
128 \\
256\end{array}$ & $\begin{array}{c}++ \\
+ \\
+ \\
+ \\
0\end{array}$ & $\begin{array}{c}++ \\
++ \\
++ \\
++ \\
+ \\
+ \\
0 \\
0\end{array}$ & $\begin{array}{c}+++ \\
+++ \\
++ \\
++ \\
+ \\
0 \\
0 \\
0\end{array}$ & $\begin{array}{c}++ \\
++ \\
+ \\
\mathbf{0} \\
\mathbf{0} \\
0 \\
0 \\
0\end{array}$ & $\begin{array}{l}+ \\
+ \\
0 \\
0 \\
0 \\
0 \\
0 \\
0\end{array}$ & $\begin{array}{l}+ \\
\mathbf{0} \\
\mathbf{0} \\
\mathbf{0} \\
\mathbf{0} \\
\mathbf{0} \\
\mathbf{0} \\
\mathbf{0}\end{array}$ & $\begin{array}{l}\mathbf{0} \\
0 \\
0 \\
\mathbf{0} \\
\mathbf{0} \\
\mathbf{0} \\
\mathbf{0} \\
\mathbf{0}\end{array}$ & $\begin{array}{l}\mathbf{0} \\
\mathbf{0} \\
\mathbf{0} \\
\mathbf{0} \\
\mathbf{0} \\
\mathbf{0} \\
\mathbf{0} \\
\mathbf{0}\end{array}$ \\
\hline
\end{tabular}

See footnotes, Table I.

is outlined in Table III. When erythrocytes were chilled in heat-inactivated $\mathrm{PCH}$ serum in the presence of complement, as in tubes 1 and 2 , fixation of hemolysin occurred as indicated by their agglutination in a 1-128 dilution of antiglobulin serum. Cells chilled in serum alone (tube 3 ), or in saline (tube 4), were not agglutinated by a 1-4 dilution of antiglobulin serum.

When the sensitized cells were washed and incubated at $37^{\circ} \mathrm{C}$ in the presence of complement, hemolysis occurred. There was no hemolysis of sensitized cells when complement was absent during the warm phase. As shown in tube 3 , the addition of complement in the warm phase did not lead to hemolysis when complement was absent during the cold phase, nor did hemolysis occur in the complete absence of complement (tube 4).

\section{Relationship between complement requirements in two phases of Donath-Landsteiner reaction}

It was noted that much less complement was needed in the warm phase when a 1-2 dilution of complement had been used in the cold phase. Erythrocytes were chilled in a constant amount of $\mathrm{PCH}$ serum with various dilutions of complement, washed three times with saline, and then warmed in various dilutions of complement. A reciprocal relationship existed between the amounts of complement required in the cold and warm phases (Table IV). The more complement present in the cold phase, the less was needed during the warm phase. The less complement present during the cold phase, the more was needed during the warm phase. For example, when a 1-2 dilution of complement was used in the cold phase, 
hemolysis still occurred when a 1-64 dilution was used in the warm phase. When a 1-64 dilution was used in the cold phase, a $1-4$ dilution was required in the warm phase.

Relationship between amount of complement and degree of antibody fixation

Complement was not only necessary in the cold phase for the fixation of antibody, but it was found that a reciprocal relationship existed between the amount of complement present and the amount of antibody fixed. This was demonstrated in two ways : 1) by using antiglobulin serum to measure the amount of antibody adsorbed (indirect Coombs [a]), and 2) by determining the hemolysin titer of heat-inactivated serum while varying the dilution of added complement.

TABLE $V$

Relationship between amount of complement and antibody fixation

Constant amount of antibody; read for agglutination

\begin{tabular}{|c|c|c|c|c|c|c|c|c|}
\hline & \multirow{2}{*}{\begin{tabular}{|l} 
Dilu- \\
tion
\end{tabular}} & \multicolumn{7}{|c|}{ Antiglobulin serum } \\
\hline & & 4 & 8 & 16 & 32 & 64 & 128 & 256 \\
\hline 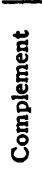 & $\begin{array}{r}2 \\
4 \\
8 \\
16 \\
32 \\
64 \\
128 \\
256\end{array}$ & $\begin{array}{c}++++ \\
+++ \\
++++ \\
+++ \\
+++ \\
++ \\
+ \\
0\end{array}$ & $\begin{array}{c}+++ \\
+++ \\
+++ \\
+++ \\
+++ \\
++ \\
+ \\
0\end{array}$ & $\begin{array}{l}0 \\
0\end{array}$ & $\begin{array}{c}++ \\
++ \\
++ \\
++ \\
+ \\
0 \\
0 \\
0\end{array}$ & $\begin{array}{r}++ \\
++ \\
++ \\
++ \\
0 \\
0 \\
0 \\
0\end{array}$ & $\begin{array}{c}+ \\
+ \\
++ \\
0 \\
0 \\
0 \\
0 \\
0\end{array}$ & $\begin{array}{l}\mathbf{0} \\
\mathbf{0} \\
\mathbf{0} \\
\mathbf{0} \\
\mathbf{0} \\
\mathbf{0} \\
\mathbf{0}\end{array}$ \\
\hline
\end{tabular}

See footnotes, Table I.

The results show that the more complement present in the cold phase, the higher the titer demonstrable on agglutination of sensitized cells by antiglobulin serum (Table V). When a 1-2 dilution of complement was used in the cold phase, the erythrocytes were agglutinated by a 1-128 dilution of antiglobulin serum. However, a 1-8 dilution of antiglobulin serum was required to agglutinate cells chilled in the presence of a 1-128 dilution of complement. When less than this amount of complement was used, no fixation of antibody was detected.

As is also true of the well-known sheep cellamboceptor hemolytic system, the more complement present the higher the antibody titer demonstrable by hemolysis of sensitized cells (Table VI). When undiluted complement was used, the $\mathrm{PCH}$ serum had a hemolysin titer of 32 . When 1-8 complement was employed, the hemolysin titer
TABLE VI

Relationship between amount of complement and antibody fixation

Decreasing amounts of antibody; read for hemolysis

\begin{tabular}{|c|c|c|c|c|c|c|c|c|}
\hline & \multirow{2}{*}{$\begin{array}{l}\text { Dilu- } \\
\text { tion- }\end{array}$} & \multicolumn{7}{|c|}{ PCH serum (antibody) } \\
\hline & & $\begin{array}{l}\text { Undi- } \\
\text { luted }\end{array}$ & 2 & 4 & 8 & 16 & 32 & 64 \\
\hline 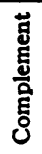 & $\begin{array}{c}\text { Undi- } \\
\text { luted } \\
2 \\
4 \\
8 \\
16\end{array}$ & $\underset{+}{++}+\underset{+}{+}+\underset{+}{+}$ & $\begin{array}{r}++ \\
++ \\
++ \\
+ \\
0\end{array}$ & $\begin{array}{r}++ \\
++ \\
++ \\
+ \\
0\end{array}$ & $\begin{array}{c}+++ \\
++ \\
+ \\
0 \\
0\end{array}$ & $\begin{array}{c}++ \\
+ \\
\mathbf{0} \\
\mathbf{0} \\
\mathbf{0}\end{array}$ & $\begin{array}{l}+ \\
\mathbf{0} \\
0 \\
0 \\
0\end{array}$ & $\begin{array}{l}\mathbf{0} \\
\mathbf{0} \\
\mathbf{0} \\
\mathbf{0} \\
\mathbf{0}\end{array}$ \\
\hline
\end{tabular}

See footnotes, Table I.

was only 4 and the degree of hemolysis was reduced.

\section{The role of the components of complement}

The fact that complement was required for union of antigen and antibody as well as for hemolysis, and that antibody fixation occurred only in the cold, marked this as an unusual antigenantibody system. Accordingly, the behavior of the various components of complement was investigated to determine if their mode of action differed from that found in the conventional sheep cell-amboceptor hemolytic system (17).

Heat-inactivated $\mathrm{PCH}$ serum and erythrocytes, in the same amounts used for hemolysin titration, were chilled with the four fractions of guinea pig serum, each fraction lacking one of the components of complement (Table VII). The cells were then washed and warmed in the presence of intact complement. Cells chilled in the fractions lacking $C^{\prime} 1$, $C^{\prime} 2$, and $C^{\prime} 3$ were hemolyzed. Only cells chilled

TABLE VII

Action of guinea pig serum fractions each lacking one component of complement

\begin{tabular}{|c|c|c|}
\hline Cold phase & Warm phase & Hemolysis \\
\hline $\begin{array}{c}\text { Missing component } \\
C_{C^{\prime} 1}^{\prime} \\
C_{2}^{\prime 2} \\
C^{\prime} 3 \\
C_{4}^{\prime} 4\end{array}$ & $\begin{array}{l}\text { Intact complement } \\
\text { Intact complement } \\
\text { Intact complement } \\
\text { Intact complement }\end{array}$ & + \\
\hline $\begin{array}{l}\text { Intact complement } \\
\text { Intact complement } \\
\text { Intact complement } \\
\text { Intact complement }\end{array}$ & $\begin{array}{c}\text { Missing component } \\
C_{C^{\prime} 1}^{C_{2}^{\prime} 2} \\
C^{\prime} 3 \\
C^{\prime} 4\end{array}$ & $\begin{array}{l}+\underset{0}{+}+ \\
+++ \\
++\end{array}$ \\
\hline Intact complement & Intact complement & $+t+$ \\
\hline
\end{tabular}

See footnotes, Table I. 
in that fraction lacking $\mathrm{C}^{\prime} 4$ did not hemolyze. The procedure was then reversed. Inactivated $\mathrm{PCH}$ serum and cells were chilled in the presence of intact complement (Table VII). The cells were then washed and warmed in the four fractions of guinea pig serum. Cells warmed in the fractions lacking $C^{\prime} 1, C^{\prime} 3$ and $C^{\prime} 4$ were hemolyzed. Only cells warmed in that fraction lacking $\mathrm{C}^{\prime} 2$ did not hemolyze.

When the four fractions were used in both the cold and warm phases (Table VIII), the various combinations again indicated that intact complement was not necessary for hemolysis. Hemolysis occurred if $C^{\prime} 1$ and $C^{\prime} 3$ were absent in both phases. When $C^{\prime} 4$ was missing in the cold phase, no hemolysis occurred. The weak hemolysis obtained with the fraction lacking $C^{\prime} 3$ can be attributed to the fact that this fraction contains less $\mathrm{C}^{\prime} 4$ than the two other fractions. When $\mathrm{C}^{\prime} 2$ was missing in the warm phase, no hemolysis occurred. There was a single exception: when $\mathrm{C}^{\prime} 2$ was missing in the cold phase and $C^{\prime} 4$ was missing in the warm phase, no hemolysis occurred.

Since $C^{\prime} 4$ retains its activity after heating at $56^{\circ} \mathrm{C}$ for 30 minutes (15) it was thought that heated guinea pig serum might provide the $\mathrm{C}^{\prime} 4$ activity needed in the cold phase of the DonathLandsteiner reaction. This was not the case, because adsorption of antibody could not be demonstrated either by agglutination of the erythrocytes or by their subsequent hemolysis on the addition of complement in the warm phase. There was no indication that $C^{\prime} 4$ from heated serum was fixed along with "inactive" $\mathrm{C}^{\prime} 2$, thus blocking the later action of $C^{\prime} 2$ in the warm phase. Erythrocytes, previously chilled in heat-inactivated guinea pig serum and $\mathrm{PCH}$ serum and washed, still adsorbed

TABLE VIII

Action of guinea pig serum fractions each lacking one component of complement

Constant amount of antibody; read for hemolysis

\begin{tabular}{c|c|c|c|c|c}
\hline \hline \multirow{1}{*}{$\begin{array}{c}\text { Missing } \\
\text { component }\end{array}$} & \multicolumn{4}{|c}{ Warm phase } \\
\cline { 2 - 5 } & & $C^{\prime} 1$ & $C^{\prime 2}$ & $C^{\prime 3}$ & $C^{\prime 4}$ \\
\hline \multirow{4}{*}{$\begin{array}{c}\text { Cold } \\
\text { phase }\end{array}$} & $C^{\prime} 1$ & ++ & 0 & ++ & +++ \\
& $C^{\prime} 2$ & ++ & 0 & ++ & 0 \\
& $C^{\prime} 3$ & + & 0 & + & + \\
& $C^{\prime} 4$ & 0 & 0 & 0 & 0 \\
\hline
\end{tabular}

See footnotes, Table I.
TABLE IX

Action of human and guinea pig sera in Donath-Landsteiner reaction

Constant amount of antibody; read for hemolysis

\begin{tabular}{l|c|c|c|c|c|c}
\hline \hline \multirow{2}{*}{$\begin{array}{c}\text { Complement } \\
\text { source }\end{array}$} & \multicolumn{6}{|c}{ Dilution of serum } \\
\cline { 2 - 6 } & $\begin{array}{c}\text { Undi- } \\
\text { luted }\end{array}$ & 2 & 4 & 8 & 16 & 32 \\
\hline Human 1 & ++ & + & 0 & 0 & 0 & 0 \\
Human 2 & ++ & + & 0 & 0 & 0 & 0 \\
Human 3 & ++ & + & 0 & 0 & 0 & 0 \\
Guinea pig & +++ & +++ & ++ & + & 0 & 0 \\
\hline
\end{tabular}

See footnotes, Table I.

antibody and were hemolyzed in the presence of fresh complement and $\mathrm{PCH}$ serum.

\section{Comparison of human and guinea pig complements}

Since human complement obviously is sufficient for in vivo hemolysis and may be adequate for in vitro hemolysis, comparison was made of the activity of intact human and guinea pig complements. Three undiluted human sera of the same blood group as the $\mathrm{PCH}$ serum were used as complement in the Donath-Landsteiner reaction. All undiluted sera produced hemolysis, but when the sera were diluted 1-2, hemolysis was weak or absent. All sera, however, possessed a high titer of complement activity for a sheep erythrocyteamboceptor system; each contained one unit in $0.15 \mathrm{ml}$. of a 1-15 dilution. Guinea pig complement titrated at the same time showed one unit in $0.15 \mathrm{ml}$. of a 1-25 dilution, i.e., the guinea pig complement was nearly twice as active as the human complement.

The three human sera and the guinea pig serum were then used in varying dilutions as the source of complement in the Donath-Landsteiner reaction (Table IX). The guinea pig serum was four times as active as the human sera. Since the $C^{\prime} 2$ and $C^{\prime} 4$ components are essential for the Donath-Landsteiner reaction, these findings are in keeping with the fact that the differences in activity between guinea pig and human sera may be due to the lower content of $C^{\prime} 2$ and $C^{\prime} 4$ in human serum (18).

\section{DISCUSSION}

The need for complement in the hemolytic reaction of paroxysmal cold hemoglobinuria was recognized by Donath and Landsteiner (1) when 
they first described their studies on three cases. This requirement has been repeatedly confirmed (2-10), and Mackenzie (3) reported that some of the failures to obtain positive Donath-Landsteiner reactions in patients having otherwise typical manifestations of the disease were due to the $a b$ sence of complement in the patient's serum.

The experiences with the serum of case 2 were somewhat similar. This serum contained enough complement for in vivo hemolysis and showed complement activity when tested with a sheep-cell amboceptor system. Nevertheless, the addition of the conventional 1-10 or 1-5 dilution of guinea pig serum would not produce a positive DonathLandsteiner reaction. It then became apparent that unusually large amounts of complement may be necessary for in vitro hemolysis. The use of an adequate amount of complement also restored the activity of serum (case 1) in which the hemolysin had been previously thought to have been inactivated by heat. Thus, the use of an inadequate amount of complement not only failed to detect $\mathrm{PCH}$ hemolysin in the serum from one patient, but also led to the erroneous conclusion that the hemolysin in the serum from another patient was heat-labile. When adequate amounts of complement were used, the hemolysins from both patients were found to be stable at $62^{\circ} \mathrm{C}$. It is not possible to generalize on the basis of a study of only two cases," but this experience offers an explanation for the previously noted thermolability of the hemolysins from some patients. It is suggested, therefore, that the reported variations in the heatstability of the hemolysin in paroxysmal cold hemoglobinuria may be attributed to inactivation of human complement and the failure to add adequate amounts of the components necessary for the activity of the hemolysin.

The results indicate further that full restoration of complement activity is necessary for measurement of the hemolysin titer. Quantitation of the hemolysin requires an excess of complement, for a reciprocal relationship exists between the

\footnotetext{
4 Since the preparation of this report, the heat stability of the antibodies in the sera from four other cases has been tested. All were found to be active after heating at $56^{\circ} \mathrm{C}$ for 30 minutes. The hemolysin in the serum of one patient (case 1 of Siebens, Zinkham, and Wagley [10]) was initially reported to be more thermolabile than complement when heated at $56^{\circ} \mathrm{C}$.
}

amount of complement present and the antibody titer.

In the presence of an adequate amount of complement, the antibody titer can be measured in two ways. Hemolysin titration in the DonathLandsteiner reaction provides one criterion of antibody level. Agglutination by antiglobulin serum of cells sensitized in dilutions of $\mathrm{PCH}$ serum (indirect Coombs [b]) provides a second criterion. The results obtained with the two methods are comparable, although the agglutination titer is occasionally one dilution higher than the hemolysin titer. Since an excess of complement is used for both hemolysin and indirect Coombs titrations, this difference can not be attributed to the fact that less complement is needed for antibody fixation than for subsequent hemolysis. The slightly higher titers obtained with the indirect Coombs test (b) probably mean that less antibody is needed on the surface of the erythrocyte to react with antiglobulin serum than is needed to induce hemolysis.

It is clear that adsorbing a whole serum and then testing the erythrocytes in dilutions of antiglobulin serum (indirect Coombs [a]) does not accurately measure the antibody content of that serum. In certain cases of acquired hemolytic anemia direct testing for erythrocyte antibody may be the only method available $(12,19-22)$. When serum antibody is present erythrocytes should be sensitized in serial dilutions of the serum and then tested with potent antiglobulin serum (23).

In agreement with other reports $(4-8,10)$ it was noted that complement is essential during both the cold and warm phases of the DonathLandsteiner reaction. Furthermore, there is a reciprocal relationship between the amounts of intact complement required in these two phases. It is possible that failure to recognize this relationship accounted for some of the discrepancies relative to the need for complement in the cold phase.

It has long been known that hemolysis is dependent on complement in the usual erythrocyteamboceptor system. In the absence of complement, antigen and antibody will still combine as evidenced by agglutination. Complement may accelerate other antigen-antibody systems (24), but the reactions occur in the absence of complement. In contrast, the immunological character of paroxysmal cold hemoglobinuria is unique in that 
it requires complement for antibody fixation as well as for subsequent hemolysis. Characterization of the $\mathrm{PCH}$ antibody has not helped to explain this phenomenon, since the hemolysin is a gammaglobulin of the pseudoglobulin type (25) and thus falls in the same class as other antibodies.

The $\mathrm{PCH}$ hemolytic system is unique in another respect because all components of complement are not necessary for hemolysis. In conventional hemolytic antigen-antibody reactions, the four components are all required for hemolysis and act as follows (17) : $C^{\prime} 4$ combines with the red cell first or simultaneously with $C^{\prime} 1$, and the fixation of $C^{\prime} 4$ predetermines the hemolytic activity of combining $C^{\prime} 1$. The fixation of $C^{\prime} 4$ is accompanied by the fixation of $C^{\prime} 2$. The erythrocyte-antibody complex is thus rendered amenable to the action of $C^{\prime} 3$ and hemolysis results. In the erythrocyte- $\mathrm{PCH}$ hemolysin system, however, $C^{\prime} 1$ and $C^{\prime} 3$ are not essential. $C^{\prime} 4$ apparently combines in the cold phase, and hemolysis occurs when $\mathrm{C}^{\prime} 2$ is present in the warm phase. These findings may appear to be at variance with Mackenzie's statement that it is chiefly, if not exclusively, "midpiece" of complement which fixes in the cold (3). This conclusion was based on the use of the sheep cell-amboceptor reaction as an indicator system for measuring residual complementary activity. "Midpiece" as formerly prepared, contains $C^{\prime} 1, C^{\prime} 3$ and $C^{\prime} 4$. Since the absence of any one of these components in Mackenzie's indicator system would have prevented hemolysis, Mackenzie may have been measuring the fixation of $\mathrm{C}^{\prime} 4$, which would be in accord with the present findings.

Since only two components of complement are required for hemolysis in paroxysmal cold hemoglobinuria, titration of complement in a patient's serum by the sheep cell-amboceptor system may not measure the capacity of that serum to produce hemolysis with the $\mathrm{PCH}$ antibody. Although such a titration would detect the presence of all the components, it would not distinguish one absent component from another. One could then erroneously conclude that spontaneous attacks of hemoglobinuria do not require complement (26).

Another problem relative to the action of complement is evident from the results obtained with serum from case 2 . This patient had spontaneous attacks of hemoglobinuria, indicating that his serum contained adequate complement for in vivo hemolysis. A positive Donath-Landsteiner reaction could not be obtained with the patient's serum alone, however, indicating that his serum did not contain enough complement for in vitro hemolysis. Yet his serum showed a high level of complement activity against sensitized sheep cells. The most obvious explanations for these findings are first, that less complement is required for $\mathrm{PCH}$ hemolysis in vivo than in vitro, and second, that the sheep cell-amboceptor system does not quantitate the components of complement needed for in vitro hemolysis in the Donath-Landsteiner reaction. Human serum does promote hemolysis in this reaction, but it is less active than guinea pig serum. This finding is in keeping with the observation (18) that guinea pig serum contains more $C^{\prime} 2$ and $C^{\prime} 4$ than does human serum.

$C^{\prime} 2$ and $C^{\prime} 4$ are now thought to be closely related, existing as a carbohydrate-protein complex in a muco-euglobin isolated from guinea pig serum (14-17). It is probable that the function of these two components in paroxysmal cold hemoglobinuria is more complex than the present studies indicate. This is suggested by the observations that when $C^{\prime} 2$ is missing in the cold phase and $C^{\prime} 4$ is missing in the warm phase, no hemolysis occurs, and that heated guinea pig serum fails to supply $\mathrm{C}^{\prime} 4$ in the cold phase. It is obviously more desirable to measure the activity of a component by its presence than by its absence. Complete elucidation of the mechanism will be sought by obtaining purified antibody and single, pure components of complement. Such studies should clarify the reciprocal relationship between the need for complement in the two phases of the Donath-Landsteiner reaction. More than one component of complement may be fixed when intact complement is used in the cold phase, and there may be no reciprocal relationship between single components of complement. The availability of single components will also permit evaluation of their effect on the intensity of the hemolytic reaction. Purified $C^{\prime} 4$ will be necessary to understand the failure of heated guinea pig serum to supply $C^{\prime} 4$ in the cold phase.

The Donath-Landsteiner reaction is apparently dependent on a more unusual type of hemolytic mechanism than was originally thought to be the case. Not only is the antibody produced to homologous tissue components in an unexplained 
manner, but the complement requirements are unique among the known antigen-antibody hemolytic systems. It is obvious that the present report has only clarified some of the qualitative aspects of the kinetics of $\mathrm{PCH}$ hemolysis. It is hoped that the availability of purified $\mathrm{PCH}$ antibody and single components of complement will permit elucidation of the $\mathrm{PCH}$ hemolytic system.

\section{SUMMARY}

Studies of sera from two patients with paroxysmal cold hemoglobinuria $(\mathrm{PCH})$ have shown that large amounts of complement may be necessary for hemolysis in the Donath-Landsteiner reaction. By using an adequate amount of complement, the hemolysins from both patients were found to be stable at $62^{\circ} \mathrm{C}$.

An excess of complement is necessary for antibody titration, since a reciprocal relationship exists between the amount of complement present and the antibody titer. Agglutination by antiglobulin serum of erythrocytes sensitized in dilutions of $\mathrm{PCH}$ serum provides another measure of antibody level, the titers obtained being comparable to those found by hemolysin titration in the DonathLandsteiner reaction.

Complement is essential in both the cold and warm phases of this reaction, and there is a reciprocal relationship between the amounts of intact complement required in these two phases. The erythrocyte- $\mathrm{PCH}$ antibody system is unique in that it requires complement for antibody fixation as well as for subsequent hemolysis.

The $\mathrm{PCH}$ hemolytic system is unusual in another respect, because all components of complement are not necessary for hemolysis. Hemolysis occurs in the absence of $C^{\prime} 1$ and $C^{\prime} 3$. Hemolysis does not occur when $\mathrm{C}^{\prime} 4$ is missing in the cold phase, or when $\mathrm{C}^{\prime} 2$ is missing in the warm phase.

Since only two components of complement are required for hemolysis in $\mathrm{PCH}$, titration of complement in a serum by the sheep cell-amboceptor system, which requires all four components, may not measure the capacity of that serum to produce hemolysis with $\mathrm{PCH}$ antibody.

\section{ACKNOWLEDGMENT}

The technical assistance of Miss Marjorie Newton and Miss Sylvia Rowihab is gratefully acknowledged.

\section{APPENDIX}

Case 1. The patient, a 30 year old white waitress, entered the hospital in April, 1948. During the four preceding winter months she had experienced eight to ten attacks characterized by chills, nausea and vomiting, pain in the back and the passage of red urine. Each attack was precipitated by exposure to cold in addition to exercise, usually after a walk to and a long wait at a bus stop. She had been married to a sailor for five years. The husband gave no history of venereal disease but was found to have a positive serological test for syphilis.

Physical examination revealed that the temperature was $37.5^{\circ} \mathrm{C}$, the pulse 84 , respirations 20 , and blood pressure $105 / 65$. The right pupil was smaller than the left, and both reacted sluggishly to light. There were no other significant abnormalities.

\section{The laboratory findings were as follows:}

Urine: no cells or albumin; benzedine and porphyrin tests negative; urobilinogen, 0.64 Ehrlich units in twohour specimen; urea clearance, 75 per cent in two hours. Blood: erythrocytes, 3,200,000; hemoglobin, $12 \mathrm{gm}$.; leucocytes, 8,700; differential count: neutrophiles, 60 per cent; lymphocytes, 33 per cent; monocytes, 5 per cent; eosinophiles, 2 per cent. Her erythrocytes were group $\mathrm{O}, \mathrm{Rh}$ positive. Erythrocyte osmotic fragility, bleeding time and clotting time were normal. Ham's acid hemolysis test was negative. Wassermann and Kline tests were positive. The Donath-Landsteiner reaction was positive, the hemolysin titer being 64 . The cold hemagglutinin (27) titer was 32. Spinal fluid: cell count, 130, of which all were mononuclear cells; protein $100 \mathrm{mg} . / 100 \mathrm{ml}$.; gum mastic 443210000 ; Wassermann, positive. A roentgenogram of the chest was normal.

The patient was afebrile and asymptomatic during the first week in the hospital. Daily urinalyses were normal. Her hand was placed in ice water for 20 minutes. The hand became swollen, but no other change was detected. The application of cold, wet sheets to her body likewise failed to induce an attack. She was then placed in a cold room at $5-6^{\circ} \mathrm{C}$ for 25 minutes. During this time she exercised for two five-minute periods by stepping up and down on a stool. At the end of the chilling period, the patient stated that she did not feel cold. The vessels of her sclerae, as observed with a slit lamp, initially showed constriction; as the vessels became dilated, the blood flow was sluggish and aggregation of erythrocytes was apparent. She was put to bed and covered with blankets. Fifty minutes after leaving the cold room, she had a shaking chill and her temperature rose to $38.5^{\circ} \mathrm{C}$. The period of rigor lasted for five minutes; a feeling of chilliness persisted for another 30 minutes; she had no nausea, vomiting, or backache. There was no change in the color of the urine; a specimen voided 15 minutes after the beginning of the reaction gave a negative benzedine test; a specimen voided $\mathbf{4 0}$ minutes later was faintly positive. Serum hemoglobin levels rose as follows: before chilling, $6 \mathrm{mg} . / 100 \mathrm{ml}$; ten minutes after chilling, 62 mg. $/ 100 \mathrm{ml}$; two hours after chilling, $56 \mathrm{mg} . / 100 \mathrm{ml}$. 
Blood hemoglobin fell from $12.1 \mathrm{gm}$. to $11.1 \mathrm{gm}$; t the hematocrit fell from 39 per cent to 36 per cent. No significant change in urine urobilinogen was detected. She stated that the attack was not as severe as those that occurred prior to hospitalization. As soon as the feeling of chilliness disappeared, she felt well, although she remained febrile for three hours.

She was treated with $2 \mathrm{ml}$. of bismuth subsalicylate, intramuscularly, twice weekly for two weeks and then given a total of 9.0 million units of penicillin. Lumbar puncture showed a drop of the mononuclear cell count from 130 to 28. Exposure to cold with exercise was repeated in the cold room, but the patient had no detectable reaction. The hemolysin titer was unchanged. She was symptom free during the month (May) following discharge at which time she left the city and further observation was not possible.

Case 2. The patient, a 27 year old colored male, entered the hospital in November, 1949, because he had voided red urine on two occasions. These attacks occurred a week apart and were both associated with exposure to cold while working outdoors. His job as a salvage inspector kept him indoors, and he believed that his exposures to cold on two successive Saturday afternoons were the first of the winter. After working in the cold for about an hour, he noted frequency and urgency and observed that his urine was pink. After working longer, he remained indoors. Shortly after he began to feel warm, he had a shaking chill, his skin "prickled," "tingled" and was sensitive to touch, and he voided dark red urine. He had no rash, backache, nausea or vomiting. Successive urine specimens showed less and less color, and he soon felt well. He had a penile lesion one year before and was told that microscopic and serological tests were negative.

Physical examination revealed no significant abnormalities. The temperature was $37^{\circ} \mathrm{C}$, the pulse 72 , respirations 18 and blood pressure 120/70.

\section{The laboratory findings were as follows:}

Urine : normal. Blood: erythrocytes, 5,287, 000; hemoglobin, $15.3 \mathrm{gm}$.; leucocytes, 5,500; differential count: neutrophiles, 72 per cent; lymphocytes, 21 per cent ; monocytes, 7 per cent. His erythrocytes were group $B, R h$ positive. Erythrocyte osmotic fragility was normal. Ham's acid hemolysis test was negative. Wassermann and Kline tests were positive. The Donath-Landsteiner reaction was positive, the hemolysin titer being 4 . The patient's washed erythrocytes were agglutinated by antiglobin serum (positive, direct Coombs test). Cold hemagglutinins (27) were not detected in a dilution of $1-4$. The spinal fluid was normal. A roentgenogram of the chest and intravenous pyelograms were normal.

Unless chilled, the patient remained afebrile and asymptomatic. Hemoglobinemia and hemoglobinuria were easily produced by placing his hand in ice water (positive Rosenthal test). This was done on three occasions, and each time there was also a leucopenia and fall in hematocrit. Twice the patient had a shaking chill and noted the skin sensation previously described. His blood pressure rose from $120 / 64$ to $130 / 84$. There was no increase in temperature. Except for discomfort in the chilled hand, the patient felt well within an hour. Hemoglobinuria persisted for about three hours.

The patient was treated with 7.2 million units of penicillin. A total of $1,500 \mathrm{ml}$. of blood have subsequently been removed, $1,000 \mathrm{ml}$. being replaced by an equal amount of whole blood of the same type. There has been a slight fall in the quantitative Kline titer, but no detectable change in the hemolysin titer. He has continued to have attacks of hemoglobinuria on exposure to cold.

\section{REFERENCES}

1. Donath, J., and Landsteiner, K., Ueber paroxysmale Hämoglobinurie. München med. Wchnschr., 1904, $51,1590$.

2a. Mackenzie, G. M., Observations on paroxysmal hemoglobinuria. J. Clin. Invest., 1929, 7, 27.

b. Eagle, H., The Laboratory Diagnosis of Syphilis. C. V. Mosby Co., St. Louis, 1937, p. 149.

3. Mackenzie, G. M., Paroxysmal hemoglobinuria; a review. Medicine, 1929, 8, 159.

4. Yorke, W., and Macfie, J. W. S., The mechanism of autolysis in paroxysmal haemoglobinuria. Brit. J. Exper. Path., 1921, 2, 115.

5. Hoover, C. F., and Stone, C. W., Paroxysmal hemoglobinuria : account of two cases. Arch. Int. Med., 1908, 2, 392.

6. Moss, W. L., Paroxysmal hemoglobinuria; blood studies in three cases. Bull. Johns Hopkins Hosp., 1911, 22, 238

7. Dennie, C. C., and Robertson, O. H., Study of a case of paroxysmal hemoglobinuria. Serum reaction. Urobilin and hemoglobin excretion. Arch. Int. Med., 1915, 16, 205.

8. Kumagai, T., and Ito, I., Weitere Untersuchungen über paroxysmale Hämoglobinurie. Mitt. a. d. med. Fakult. d.k. Univ. zu Tokyo, 1916-17, 16, 227.

9. Widal, F., Abrami, P., and Brissaud, E., L'autoanaphylaxie. Son rôle dans l'hémoglobinurie paroxystique. Traitement anti-anaphylactique de l'hémoglobinurie. Conception physique de l'anaphylaxie. Semana méd., 1913, 33, 613.

10. Siebens, A. A., Zinkham, W. H., and Wagley, P. F., Observations on the mechanism of hemolysis in paroxysmal (cold) hemoglobinuria. Blood, 1948, 3, 1367.

11. Coombs, R. R. A., Mourant, A. E., and Race, R. R., Detection of weak and incomplete $\mathrm{Rh}$ agglutinins: A new test. Lancet, 1945, 2, 15.

12. Evans, R. S., and Duane, R. T., Acquired hemolytic anemia. I. The relation of erythrocyte antibody production to activity of the disease. II. The significance of thrombocytopenia and leukopenia. Blood, 1949, 4, 1196.

13. Pillemer, L., and Ecker, E. E., The terminology of the components of complement. Science, 1941, 94, 437. 
14. Pillemer, L., Seifter, S., and Ecker, E. E., The role of the components of complement in specific immune fixation. J. Exper. Med., 1942, 75, 421.

15. Pillemer, L., Recent advances in the chemistry of complement. Chem. Rev., 1943, 33, 1.

16. Pillemer, L., and Ecker, E. E., Anticomplementary factor in fresh yeast. J. Biol. Chem., 1941, 137, 139.

17. Pillemer, L., Seifter, S., Chu, F., and Ecker, E. E., Function of components of complement in immune hemolysis. J. Exper. Med., 1942, 76, 93.

18. Unpublished observation.

19. Boorman, K. E., Dodd, B. E., and Loutit, J. F., Haemolytic icterus (acholuric jaundice); congenital and acquired. Lancet, 1946, 1, 812.

20. Evans, R. S., Duane, R. T., and Behrendt, F., Demonstration of antibodies in acquired hemolytic anemia with anti-human globulin rabbit serum. Proc. Soc. Exper. Biol. \& Med., 1947, 64, 372.

21. Wagley, P. F., Shen, S. C., Gardner, F. H., and Castle, W. B., Studies on the destruction of red blood cells. VI. The spleen as a source of a substance causing agglutination of the red blood cells of certain patients with acquired hemolytic jaundice by an antihuman serum rabbit serum (Coombs' serum). J. Lab. \& Clin. Med., 1948, 33, 1197.
22. Singer, K., and Motulsky, A. G., The developing (Coombs) test in spherocytic hemolytic anemias; its significance for the pathophysiology of spherocytosis and splenic hemolysis. J. Lab. \& Clin. Med., 1949, 34, 768.

23. Sturgeon, P., A new antibody in serum of patients with acquired hemolytic anemia. Science, 1947, 106, 293.

24. Ward, H. K, and Enders, J. F., An analysis of the opsonic and tropic action of normal and immune sera based on experiments with the pneumococcus. J. Exper. Med., 1933, 57, 527.

25. Jordan, W. S., Jr., Pillemer, L., and Dingle, J. H., The mechanism of hemolysis in paroxysmal cold hemoglobinuria. II. Observations on the behavior and nature of the antibody. J. Clin. Invest., 1951, 30, 22.

26. Meyer, E., and Emmerich, E., Uber paroxysmale Hämoglobinurie; klinisch-hämatologische Untersuchungen. Deutsches Arch. f. klin. Med., 1909, 96, 287.

27. Feller, A. E., Primary atypical pneumonia, in Diagnostic Procedures for Virus and Rickettsial Diseases. Am. Pub. Health Assoc., New York, 1948, 1st edition, p. 125. 